wWw.volsu.ru

DOI: https://doi.org/10.15688/jvolsu11.2017.1.7

UDC 616.72:002.77:616.89

LBC 88.481

\title{
THE ROLE OF ANXIETY IN PSYCHO-PHYSIOLOGY OF STRESS
}

\author{
Rostislav A. Grekhov \\ Research Institute of Clinical and Experimental Rheumatology; Volgograd State Medical University, \\ Volgograd, Russian Federation

\section{Galina P. Suleymanova} \\ Research Institute of Clinical and Experimental Rheumatology; Volgograd State University, \\ Volgograd, Russian Federation

\section{Ekaterina I. Adamovich} \\ Volgograd State Medical University, Volgograd, Russian Federation
}

\begin{abstract}
The article describes the concepts of anxiety, stress, and physiological mechanisms of psychosomatic relationships. The authors give existing concepts and approaches in understanding and disclosure of anxiety as psychological and psycho-physiological phenomenon. Anxiety, as a factor of emotional instability, may act as maladaptive, hindering the development of emotional and volitional, cognitive sphere, becoming emotionally-personal entities. The emotional reaction is expressed in the form of constant anxiety, acts as a link between psychological and somatic spheres. Meaning of anxiety disorders in the genesis of psychopathological phenomena defines them as a "trunk of common neurotic organization." Prolonged stress and the associated emotional tension are physiologically expressed in changing human neuro-humoral system and are implemented through the tension of the autonomic nervous system at different levels of regulation. Functional stage defeat in which gradually develops into a destructive and morphological changes in the somatic system generalization of psychosomatic diseases by "vulnerable body" and depends on the protectiveadaptive mechanisms of a particular individual. Thus, in this context psychological factor acts as a damaging factor. The emergence and strength of an anxiety disorder depends on the characteristics of a person and their stress resistance.

Key words: anxiety, psychosomatic medicine, stress, distress, mental trauma, stress resistance, intrapsychic adaptation, vegetative nervous system.
\end{abstract}

УДК 616.72:002.77:616.89

ББК 88.481

\section{РОЛЬ ТРЕВОГИ В ПСИХОФИЗИОЛОГИИ СТРЕССА}

\section{Ростислав Александрович Грехов}

Научно-исследовательский институт клинической и экспериментальной ревматологии;

Волгоградский государственный медицинский университет, г. Волгоград, Российская Федерация

\section{Галина Павловна Сулейманова}

Научно-исследовательский институт клинической и экспериментальной ревматологии; Волгоградский государственный университет, г. Волгоград, Российская Федерация

\section{Екатерина Ивановна Адамович}

Волгоградский государственный медицинский университет, г. Волгоград, Российская Федерация

Аннотация. В статье раскрываются понятия тревожности, стресса, психофизиологические механизмы формирования психосоматических взаимосвязей. Приводятся существующие концепции, подходы к пони- 
манию и раскрытию тревоги как психологического и психофизиологического феноменов. Тревожность как фактор эмоциональной нестабильности выступает дезадаптивным моментом, препятствующим развитию эмоционально-волевой, познавательной сферы, становлению эмоционально-личностных образований. Эмоциональная реакция, выражающаяся в форме постоянной тревоги, выступает связующим звеном между психологической и соматической сферами. Значение тревожных расстройств в генезе психопатологических явлений можно определить как «ствол общей невротической организации». Длительный стресс и связанная с ним эмоциональная напряженность физиологически выражаются в изменении нейрогуморальной системы человека и реализуются через напряжение вегетативной нервной системы на различных уровнях регуляции. Функциональный этап поражения постепенно перерастает в деструктивно-морфологические изменения в соматической системе с генерализацией психосоматического заболевания по «уязвимому органу» и зависит от защитно-приспособительных механизмов конкретного индивидуума. Таким образом, в данном контексте психический фактор выступает как повреждающий. Возникновение и сила тревожного расстройства зависят от особенностей данной личности и ее стрессоустойчивости.

Ключевые слова: тревога, психосоматика, стресс, дистресс, психическая травма, стрессоустойчивость, интрапсихическая адаптация, вегетативная нервная система.

Тревога - эмоциональное переживание, характеризующееся дискомфортом от неопределенности перспективы и имеющее определенный биологический смысл: мобилизация ресурсов организма, обеспечивающих поведение в экстремальных состояниях. Источником тревоги может выступать информация о семейных и служебных неприятностях, потере близких, угрозе жизни, здоровью и благополучию. Раздражитель может быть однократный сверхсильный - при этом речь идет об острой психической травме, или многократно действующий слабый - в этом случае говорят о хронической психической травме или психотравмирующей ситуации. Значимость информации именно для данного индивидуума определяет степень ее патогенности. Перечисленные факторы делают индивида уязвимым к психоэмоциональным стрессам, затрудняют психологическую и биологическую защиту, облегчают возникновение и утяжеляют течение соматических нарушений, способствуют формированию психосоматических расстройств (см.: $[1 ; 6 ; 7 ; 8 ; 9 ; 15 ; 16 ; 17 ; 18$; $19 ; 23 ; 29 ; 37])$.

Тревожность как фактор эмоциональной нестабильности выступает дезадаптивным моментом, препятствующим развитию эмоционально-волевой, познавательной сферы, становлению эмоционально-личностных образований $[9 ; 18 ; 19 ; 28]$.

Как показано многими исследователями, прежде всего важно четкое концептуальное различение понятий тревоги как состояния и тревожности как черты, свойства личности. Установлено, что «отрицательный» эмоцио- нальный баланс (преобладание личностной тревожности над реактивной) способствует возникновению признаков напряжения адаптивных систем организма (увеличение показателя активности регуляторных систем) вне зависимости от типа исходной гемодинамики. Формирование «отрицательного» эмоционального баланса способствует возникновению чрезмерного напряжения и/или перенапряжения механизмов адаптации, особенно у лиц с гипердинамическим типом кровообращения [19].

В то же время умеренная «личностная тревожность» как свойство личности может способствовать успешной деятельности, обусловливая такие черты характера, как ответственность, обязательность, исполнительность, пунктуальность, педантичность. Низкий уровень тревожности может свидетельствовать о беспечности, а чрезмерная личностная тревожность сопровождается внутренним напряжением и может дезорганизовать деятельность [20].

Тревогу рассматривают как первичный показатель неблагополучия, когда организм не имеет возможности естественным образом реализовывать потребности, и реакции личности на представленную угрозу [20; 26]. Психические проявления тревоги разнообразны: нетерпеливость, раздражительность, чрезмерное беспокойство, постоянное вспоминание и проигрывание неприятной ситуации, одержимость мрачными предчувствиями, паника и страх, различные вегетосоматические проявления $[1 ; 8 ; 9 ; 18 ; 19 ; 23 ; 25]$ :

- нарушения сна, особенно трудности засыпания, частые пробуждения среди ночи; 
- вегетативная гиперактивность (потливость, тахикардия или тахипноэ, эпигастральный дискомфорт, головокружение, сухость во рту и пр.);

- разнообразные жалобы на физическое самочувствие: слабость, головные и мышечные боли, боли в спине и пояснице (часто трактуемые как «остеохондроз»), мышечные подергивания (симптомы в большей мере обусловлены хроническим повышением мышечного тонуса, который сопровождает патологическую тревогу);

- наличие таких симптомов соматической патологии, как сердцебиение, перебои в сердце, чувство сдавливания или сжатия в груди, боли в сердце, ощущение нехватки воздуха, повышение артериального давления, дрожь, потливость, «мурашки», «гусиная» кожа, тошнота, спастические боли в животе, сухость во рту.

Эмоциональная реакция, выражающаяся в форме постоянной тревоги, выступает связующим звеном между психологической и соматической сферами $[5 ; 9 ; 14 ; 15 ; 36]$.

Полное развитие чувства тревоги предотвращается защитными физиологическими механизмами, но обычно они лишь уменьшают, а не устраняют полностью эти физиологические явления и их патогенное действие. Чаще всего эмоциональное выражение тревоги блокируется психикой путем отведения этого напряжения к соматическим структурам через вегетативную нервную систему, что, таким образом, приводит к патологическим изменениям в различных системах органов [19; 24]. Постепенно сверхактуальное переживание фиксируется, образуя установочную доминанту, являющуюся функциональным очагом психической патологической импульсации, и поражает соответствующую систему органов. Постепенно функциональный этап поражения перерастает в деструктивно-морфологические изменения в соматической системе и происходит генерализация психосоматического заболевания. Таким образом, психический фактор выступает как повреждающий $[1 ; 2 ; 5 ; 7]$.

Центром тяжести психосоматического страдания оказывается всегда орган, наиболее уязвимый и важный для жизнедеятельности организма в представлении индивида.
«Выбор органа» свидетельствует о преимущественной направленности защитно-приспособительных механизмов, вызывающих повреждающий эффект по мере нарастания дезинтеграции в стрессовых ситуациях [1]. Инициатива в выборе органа принадлежит всегда корковым связям, влияющим на эмоциональные подкорковые аппараты и программирующим степень вовлечения тех или иных органов в стрессовую ситуацию. Какой именно эффекторный путь окажется предпочтительнее для выхода на периферию эмоционального возбуждения, зависит в конечном счете от особенностей данной эмоции, нервной конституции человека и всей истории его жизни [7; 18]. Внутренние конфликты, невротические типы реакций или психореактивные связи обусловливают картину органического страдания, его длительность, течение и, возможно, резистентность к терапии $[21 ; 28$; $32 ; 33 ; 35]$.

Определенный интерес представляет исследование взаимоотношений между двумя компонентами единой реакции: психическим и вегетативно-гуморальным.

Одним из наиболее адекватных объектов изучения данного вопроса служит гипоталамический уровень регуляции и его нарушения. Это объясняется особой, «двойственной» функцией гипоталамических структур, которые, осуществляя интеграцию вегетативногуморального регулирования, в то же время играют важную роль в организации поведения, формировании его эмоциональных и мотивационных аспектов. Роль гипоталамуса определяется как «специфически построенный отдел мозга, реагирующий на малейшие колебания гуморальных показателей и формирующий в ответ на эти сдвиги целесообразные поведенческие акты» $[10 ; 14 ; 34]$.

Характер психосоматической интеграции при указанных состояниях, оцениваемый путем сопоставления в течение длительного, нередко многолетнего наблюдения психического статуса и особенностей вегетативно-гуморального регулирования (характер и интенсивность сосудистых реакций, обмен нейрогормонов (медиаторов), тиреоидных гормонов, системы гипофиз - кора надпочечников)), показал определенный стереотип изменений психосоматической интеграции, тесно связанный, 
с одной стороны, с выраженностью и стабильностью (или пароксизмальностью) тревожных расстройств, а с другой - с характером и последовательностью включения механизмов «интрапсихической адаптации» (см.: [5; 10; 13; $15 ; 19 ; 23])$.

Значение тревожных расстройств в генезе психопатологических явлений отмечено 3. Фрейдом, который назвал тревогу «стволом общей невротической организации», что потом неоднократно подтверждалось многочисленными исследователями [11].

Неоднократно описывались и вегетативно-гуморальные изменения, наступающие при тревоге настолько неизменно, что дало повод W. Poldinger выделить в синдроме тревоги как обязательные компоненты психопатологические, психомоторные и вегетативные проявления [4; 5].

Определенный интерес вызывают изменения психосоматической интеграции, возникающие при острой (пароксизмальной) тревоге, причина которой не осознается субъектом, и трансформация этих изменений в зависимости от бессознательных механизмов интрапсихической адаптации, таких как отрицание, вытеснение, фиксация тревоги, снижение общего уровня побуждений и концептуализация [9]. Так, тревога как состояние («реактивная тревожность») характеризуется временными неприятными эмоциями беспокойства, озабоченности; сопровождается активацией вегетативной нервной системы. В поведении проявляется суетливостью, ажитацией, затруднением концентрации внимания на какой-либо деятельности [9; 25].

Приоритет в выделении клинико-психологического аспекта телесности человека принадлежит C. Wernicke, который подразделил содержательные элементы психики на осознание внешнего мира (аллопсихические элементы), осознание собственной телесности (соматопсихические элементы) и осознание собственной личности (аутопсихические элементы) [11]. Вследствие кризисов развития в структуре болезни формируются психологические новообразования, которые выступают в виде следующих личностных изменений:

- снижение личностной активности, спонтанности, произвольности, поведенческой активности, выносливости, появление астении и истощаемости мотивов, падение энергии побуждений с повышенным эффектом пресыщения (мотивационная слабость);

- явления эмоциональной лабильности (раздражительной слабости) с быстрыми сменами настроения, с переходом от одной эмоции к противоположной; повышение тревожности, возникновение тревожно-депрессивных состояний, то есть тех состояний, которые в совокупности с общим падением энергии способствуют фиксации эмоции, хронизации, а следовательно, риску соматизации;

- снижение критичности в личностном отношении с повышенной внушаемостью (это две стороны одного явления), появление такого качества, как неспособность возложить ответственность на себя, с отказом от всякой ответственности и возложением этих обязанностей на медицину в целом или отдельных ее представителей [11].

Проблема психологического онтогенеза телесности и симптомообразования хорошо описана в концепции стресса или адаптационного синдрома Ганса Селье (H. Selye), в которой тревога выступает как основополагающий предиктор развития приспособительных реакций организма $[2 ; 18]$. Он рассматривал тревогу как наиболее сильнодействующий механизм психического стресса с физиологических позиций, как неспецифическую реакцию организма на любое предъявляемое к нему требование. Патогенность стресса, дистресс, имеет место в том случае, когда стресс превышает резервные возможности организма, реализуясь на психосоматическом или невротическом уровне. Наиболее тяжелой формой дистресса по Г. Селье является шок.

При благоприятных условиях это состояние может трансформироваться в оптимальное состояние, при неблагоприятных - в состояние нервно-эмоциональной напряженности, для которого характерно снижение работоспособности и эффективности функционирования систем и органов, истощение энергетических ресурсов.

Основные механизмы стресса - нейрогуморальные. Главным морфологическим признаком является так называемая классическая триада: разрастание коры надпочечников, уменьшение вилочковой железы и изъязвление желудка. Г. Селье сопоставил эти 
реакции с симптомами, характерными почти для любого заболевания, такими как чувство недомогания, разлитые болевые ощущения и чувство ломоты в суставах и мышцах, желудочно-кишечные расстройства с потерей аппетита и уменьшением веса тела.

Среди признаков стрессового напряжения выделяют: невозможность сосредоточиться; частые ошибки в работе; ухудшение памяти; частое возникновение чувства усталости; быстрая речь; мысли часто улетучиваются; довольно часто появляются боли различной локализации (в области головы, спины, желудка); повышенная возбудимость; работа не доставляет прежней радости; потеря чувства юмора; резкое возрастание количества выкуриваемых сигарет; пристрастие к алкогольным напиткам; постоянное ощущение недоедания или пропадание аппетита; невозможность вовремя закончить работу $[2 ; 18 ; 31 ; 39]$.

Экстремальные ситуации принято делить на кратковременные, когда актуализируются программы реагирования, которые в человеке всегда наготове, и на длительные, которые требуют адаптационной перестройки функциональных систем человека, иногда субъективно крайне неприятной, а подчас неблагоприятной для его здоровья.

Длительный стресс и связанная с ним эмоциональная напряженность физиологически выражаются в изменении нейрогуморальной системы человека и реализуются через напряжение вегетативной нервной системы на различных уровнях регуляции. Преодоление жизненных кризисов, особенно когда способы этого преодоления неудачны, может снизить сопротивляемость болезням из-за ослабления иммунитета, приводить к таким заболеваниям, как инсульт, патология желудочно-кишечного тракта, нарушения сна, синдром хронической усталости, ухудшение памяти, снижение концентрации, неврозы, депрессивные состояния, головные боли, головокружение, снижение иммунитета, импотенция и другие расстройства в сексуальной сфере, бронхиальная астма, ускорение старения, резкое ухудшение волос, кожи и ногтей, появление сердечно-сосудистых заболеваний, таких как гипертония, гипотония, приступы учащенного сердцебиения, стенокар- дии, возникновение некоторых кожных заболеваний, например, экземы, нейродермита, псориаза $[1 ; 2 ; 14 ; 28 ; 32 ; 35 ; 37]$.

Исследователями отмечено, что люди с напряженной вегетативной нервной системой имеют более низкую стрессоустойчивость, особенно мужчины, и более высокую предрасположенность к психосоматическим расстройствам (в сравнении со здоровыми). Чувства агрессии, тревоги и обиды в силу особенностей характера пациентов, как правило, остаются неотреагированными, вследствие чего происходит их соматизация в форме различных симптомов - от периодически возникающих колющих точечных болей в сердце после перенесенного стресса до вегетативных кризов (панических атак) [4; 5; 8].

Также, как показывают исследования, эмоциональные нарушения при адаптационном синдроме носят в основном тревожный или фобический характер. Наиболее часто наблюдается генерализованное тревожное расстройство. Оно, как правило, не связано с какойлибо конкретной стрессовой ситуацией - у пациента отмечаются в течение продолжительного времени (более шести месяцев) различные как психические (ощущение постоянного внутреннего напряжения, неспособность расслабиться, беспокойство по мелочам), так и соматические проявления. Среди последних дыхательные расстройства (чаще «пустое дыхание» или гипервентиляционные эквиваленты - кашель, зевота) могут составлять ядро клинической картины наряду, например, с аллергическими и сердечно-сосудистыми проявлениями. Значительной степени дыхательные нарушения достигают во время панической атаки, когда развивается так называемый гипервентиляционный криз. Чаще отмечаются расстройства второго и третьего типа - потеря автоматизма дыхания и затрудненное дыхание. У пациента возникает страх задохнуться и другие симптомы, характерные для панической атаки [8].

У одних реакция активная, при стрессе успешность их деятельности продолжает расти до некоторого предела («стресс льва»), а у других - пассивная, эффективность их деятельности падает сразу («стресс кролика»). У человека, как правило, постоянно подавляющего вспышки гнева, могут развиться рев- 
матоидный артрит, крапивница, псориаз, язва желудка, мигрень, гипертония [1; 7; 17].

Успешность реакции на стресс определяется таким свойством личности, как стрессоустойчивость. Стрессоустойчивость - это термин, характеризующий некоторую совокупность личностных качеств, позволяющих человеку переносить значительные интеллектуальные, волевые, эмоциональные и физические нагрузки (перегрузки) без особых вредных последствий для своего здоровья. К признакам высокой стрессоустойчивости относятся: энергетический потенциал личности; уровень развития интуиции; уровень развития логических способностей; эмоциональная зрелость личности; эмоциональная устойчивость и уровень эмоционального контроля; пластичность (гибкость, готовность личности к изменениям); сильный тип темперамента (по И.П. Павлову); высокий уровень развития рефлексии и другие $[2 ; 5]$.

Например, низкая стрессоустойчивость отмечена у пациентов с язвенной болезнью. Специфические психологические установки и личностная позиция пациентов с язвенной болезнью отличаются формированием тревожности, раздражительности, повышенной исполнительности и обостренным чувством долга. Им свойственна пониженная самооценка, сопровождающаяся чрезмерной ранимостью, стеснительностью, обидчивостью, неуверенностью в себе и вместе с этим повышенная требовательность к себе, мнительность. Также в списке заболеваний, связанных с низкой стрессоустойчивостью, доминируют неврозы - группа нервно-психических заболеваний, возникающих в основном вследствие длительных психических переживаний, перенапряжений при выполнении чрезмерных по сложности и трудоемкости дел, недостаточного отдыха, сна, длительной внутренней борьбы, необходимости скрывать горе, гнев, страдания [1;7].

Таким образом, тревога в определенной ситуации может возникать по субъективным причинам, связанным с особенностями данной личности. Тревога, по интенсивности и длительности не адекватная ситуации, препятствует формированию адаптационного поведения, приводит к нарушению поведенческой интеграции и общей дезорганизации психики человека. Следовательно, тревога лежит в основе любых изменений психического состояния и поведения, обусловленных психическим стрессом.

\section{СПИСОК ЛИТЕРАТУРЫ}

1. Березанцев, А. Ю. Соматопсихические и психосоматические расстройства: вопросы систематики и синдромологии (клинико-психологический аспект) / А. Ю. Березанцев // Медицинская психология в России. -2011 . - № 1. - Электрон. текстовые дан. - Режим доступа: http://medpsy.ru (дата обращения: 12.02.2017). - Загл. с экрана.

2. Бодров, В. А. Психологический стресс: развитие и преодоление / В. А. Бодров. - М. : ПЕР СЭ, 2006. $-528 \mathrm{c}$.

3. Бухтояров, О. В. Психогенный кофактор канцерогенеза. Возможности применения гипнотерапии / О. В. Бухтояров, А. Е. Архангельский. СПб. : Алетейа, 2008. - 264 с.

4. Дусказиева, Ж. Г. Особенности защитносовладающей системы у пациентов с вегетососудистой дистонией / Ж. Г. Дусказиева // Актуальные проблемы психологии и педагогики : материалы Bcepoc. науч. конф. с междунар. участием, 19 мая 2011 г. / под ред. В. Г. Печерского, Н. В. Зайцевой. Саратов : Изд-во СГСЭУ, 2011. -С. 137-139.

5. Дусказиева, Ж. Г. Особенности стрессоустойчивости пациентов с вегетососудистой дистонией / Ж. Г. Дусказиева // Медицинская психология в России. - 2012. - № 3 (14). - Электрон. текстовые дан. - Режим доступа: http://medpsy.ru (дата обращения: 12.02.2017). - Загл. с экрана.

6. Криз? Атака? Невроз? Клинический случай приступа психовегетативных нарушений в кардиологическом стационаре / О. В. Николаева, И. Н. Бабурин, Е. Л. Николаев, Е. А. Дубравина // Вестник психотерапии. -2009. - № 30. - С. 86-90.

7. Кукушкин, М. Л. Психогенные болевые синдромы / М. Л. Кукушкин // Боль. - 2004. - № 1 (2). - C. $2-6$.

8. Кулаков, С. А. Основы психосоматики / С. А. Кулаков. - СПб. : Речь, 2003. - 288 с.

9. Курпатов, А. В. Паническая атака и невроз сердца / А. В. Курпатов. - 4-е изд. - М. : ОЛМА Медиа Групп, 2007. -224 c.

10. Малкова, Е. Е. Тревога при соматических расстройствах у детей и подростков / Е. Е. Малкова // Медицинская психология в России. - 2012. - № 3 (14). - Электрон. текстовые дан. - Режим доступа: http://medpsy.ru (дата обращения: 12.02.2017). - Загл. с экрана.

11. Николаева, В. В. От традиционной психосоматики к психологии телесности / В. В. Николае- 
ва, Г. А. Арина // Вестник Московского университета. Серия 14, Психология. - 1996. - № 2. - С. 8-17.

12. Особенности функционального состояния вегетативной нервной системы старших школьников / Т. Г. Шанина, О. М. Филькина, Е. А. Воробьева [и др.] // Клінічна педіатрія. - 2011. - № 3 (30). - Электрон. текстовые дан. - Режим доступа: http:// pediatric.mif-ua.com/archive/issue-17332/article-21916/ (дата обращения: 12.02.2017). - Загл. с экрана.

13. Покровская, Н. В. Вегетососудистая дистония / Н. В. Покровская. - М. : АСТ ; СПб. : Сова, 2009. $-128 \mathrm{c}$.

14. Психофизиологические критерии индивидуальной реакции в ситуации острого эмоционального стресса / С. Л. Соловьева, В. И. Николаев, Н. П. Денисенко, М. Д. Денисенко // Медицинская психология в России. - 2012. - № 4 (15). - Электрон. текстовые дан. - Режим доступа: http://medpsy.ru (дата обращения: 12.02.2017). - Загл. с экрана.

15. Рагозинская, В. Г. Нейрофизиологические корреляты эмоциональных состояний у пациентов с психосоматическими расстройствами / В. Г. Рагозинская, С. Л. Соловьева, В. И. Николаев // Медицинская психология. - 2009. - № 2 (31). - С. 202-205.

16. Ромасенко, Л. В. К характеристике психосоматических отношений у больных нейроциркуляторной дистонией / Л. В. Ромасенко, О.Ю.Веденяпина, А. В. Вербина // Психиатрия и психофармакотерапия. - 2002. - Т. 4, № 1. - С. 12-16.

17. Самушия, М. А. Нозогении (психогенные реакции) у женщин со злокачественными опухолями органов репродуктивной системы / М. А. Самушия, Е. А. Мустафина // Психические расстройства в общей медицине. - 2007. - № 3. - С. 11-16.

18. Симаненков, В. И. Функциональные и психосоматические расстройства желудочно-кишечного тракта / В. И. Симаненков, В. Б. Гриневич, И. В. Потапова. -СПб. : ЛСП, 2006. -651 с.

19. Смулевич, А. Б. Психопатология личности и коморбидные расстройства / А. Б. Смулевич. М. : МЕДпресс-информ, 2009. - 206 с.

20. Соловьева, С. Л. Тревога и тревожность: теория и практика / С. Л. Соловьева // Медицинская психология в России. -2012. - № 6 (17). - Электрон. текстовые дан. - Режим доступа: http://medpsy.ru (дата обращения: 12.02.2017). - Загл. с экрана.

21. Старшенбаум, Г. В. Психосоматика и психотерапия. Исцеление души и тела / Г. В. Старшенбаум. - М. : Изд-во Института психотерапии, 2005. $496 \mathrm{c}$.

22. Тхостов, А. Ш. Обратная сторона социализации. Влияние современных технологий на развитие личности и формирование патологических форм адаптации / А. Ш. Тхостов, К. Г. Сурнов // Психологический журнал. - 2005. - Т. 26, № 6. C. 16-24.
23. Успенский, Ю. П. Тревожные расстройства и их коррекция в гастроэнтерологической практике / Ю. П. Успенский, Е. В. Балукова // ConsiliumMedicum. - 2008. - № 2. - Электрон. текстовые дан. Режим доступа: http://www.gastroscan.ru/literature/ authors/2200 (дата обращения: 12.02.2017). - Загл. с экрана.

24. Чистякова, А. И. Психофизиология стресса / А. И. Чистякова // Журнал естественнонаучных исследований. - 2016. - Т. 1, № 5. - С. 2.

25. Чутко, Л. С. Тревожные расстройства у детей и подростков / Л. С. Чутко // Тревожные расстройства в общеврачебной практике : руководство для врачей. - СПб. : ЭЛСБИ-СПб, 2010. - С. 55-74.

26. Anxiety symptom presentations in Han Chinese and Euro-Canadian outpatients: Is distress always somatized in China? / X. Zhou, J. Dere, X. Zhu, S. Yao // Journal of Affective Disorders. - 2011. Vol. 135, № 1-3. - P. 111-114.

27. Ayers, S. Cambridge handbook of psychology, health and medicine / S. Ayers, A. Baum, Chr. McManus. - Cambridge : University Press, 2007. $304 \mathrm{p}$.

28. Metabolic characteristics of brain structures during conscious and unconscious anxiety / T. N. Reznikova, I. Yu. Terentyeva, G. V. Kataeva, V. I. Semivolos // Human Physiology. - 2008. - Vol. 34, № 5. - P. 539-545.

29. Murray, L. The development of anxiety disorders in childhood: an integrative review / L. Murray, C. Creswell, P. Cooper // Psychological Medicine.-2009. - Vol. 39 (9). - P. 1413-1423.

30. Noyes, R. The anxiety disorders / R. Noyes, R. Hoehn-Saric. - Cambridge University Press, 1998. $303 \mathrm{p}$.

31. Porcelli, P. Criteria for psychosomatic research (DCPR) in the medical setting / P. Porcelli, C. Rafanelli // Curr. Psychiatry Rep. - 2010. - Vol. 12 (3). - P. 246-254.

32. Rao, D. Culture, somatization, and psychological distress: Symptom presentation in South Indians patients from a public psychiatric hospital / D. Rao, M. Young, R. Raguram // Psychopathology. - 2007. - Vol. 40, № 5. P. 349-355.

33. Smoller, J. Genetics of anxiety disorders: the complex road from DSM to DNA / J. Smoller, S. Block, M. Young // Depress Anxiety. - 2009. - Vol. 26 (11). P. 965-975.

34. The relationship between cognitive functions, somatization and behavioural coping in patients with multiple functional somatic symptoms / N. M. Hall, R. Kuzminskyte, A. D. Pedersen, E. Ornbool // Nordic Journal of Psychiatry. - 2011. Vol. 65, № 3. - P. 216-224.

35. Theory of mind and emotional awareness deficits in patients with somatoform disorders 
/ C. Wrana, M. E. Beutel, A. Knebel, R. D. Lane // Psychosomatic Medicine. - 2010. - Vol. 72, № 4. P. $404-411$.

36. Von Känel, R. Psychosocial stress and cardiovascular risk: current opinion / R. Von Känel // Swiss. Med. Wkly. - 2012. - № 142. - P. 13-24.

37. Waller, E. Somatoform disorders as disorders of affect regulation: a developmental perspective / E. Waller, C. E. Scheidt // International Review of Psychiatry. - 2006. - Vol. 18, № 1. - P. 13-24.

38. Weiss, J. Psychocardiology: one heart and one soul / J. Weiss // Dtsch. Med. Wochenschr. 2010. - Bd. 135 (3). - S. 2.

\section{REFERENCES}

1. Berezantsev A.Yu. Somatopsikhicheskie i psikhosomaticheskie rasstroystva: voprosy sistematiki i sindromologii (kliniko-psikhologicheskiy aspekt) [Somatopsychic and Psychosomatic Disorders: Issues of Systematics and Syndromology (Clinical and Psychological Aspect)]. Meditsinskaya psikhologiya v Rossii, 2011, no. 1. URL: http://medpsy.ru. (accessed February 12, 2017).

2. Bodrov V.A. Psikhologicheskiy stress: razvitie i preodolenie [Psychological Stress: Development and Overcoming]. Moscow, PER SE Publ., 2006. 528 p.

3. Bukhtoyarov O.V., Arkhangelskiy A.E. Psikhogennyy kofaktor kantserogeneza. Vozmozhnosti primeneniya gipnoterapii [Psychogenic Co-factor of Carcinogenesis. Possibilities of Using Hypnotherapy]. Saint Petersburg, Aleteya Publ., 2008. 264 p.

4. Duskazieva Zh. G. Osobennosti zashchitnosovladayushchey sistemy $u$ patsientov $s$ vegetososudistoy distoniey [Features of the Protective-Coping System in Patients with Vegetovascular Dystonia]. Pecherskiy V.G., Zaytseva N.V., eds. Aktualnye problemy psikhologii i pedagogiki: materialy Vseros. nauch. konf. s mezhdunar. uchastiem, 19 maya 2011 g. [Current Problems of Psychology and Pedagogy: Proceedings of All-Russian Scientific Conference with International Participation, May 19, 2011]. Saratov, Izd-vo SGSEU, 2011,pp. 137-139.

5. Duskazieva Zh.G. Osobennosti stressoustoychivosti patsientov s vegetososudistoy distoniey [Features of Stress Resistance of Patients with Vegetovascular Dystonia]. Meditsinskaya psikhologiya v Rossii, 2012, no. 3 (14). URL: http://medpsy.ru. (accessed February 12, 2017).

6. Nikolaeva O.V., Baburin I.N., Nikolaev E.L., Dubravina E.A. Kriz? Ataka? Nevroz? Klinicheskiy sluchay pristupa psikhovegetativnykh narusheniy $\mathrm{v}$ kardiologicheskom statsionare [Crisis? Attack?
Neurosis? Clinical Case of an Attack of PsychoVegetative Disorders in a Cardiac Hospital]. Vestnik psikhoterapii, 2009, no. 30, pp. 86-90.

7. Kukushkin M.L. Psikhogennye bolevye sindromy [Psychogenic Pain Syndromes]. Bol, 2004, no. 1 (2), pp. 2-6.

8. Kulakov S.A. Osnovy psikhosomatiki [Fundamentals of Psychosomatics]. Saint Petersburg, Rech Publ., 2003. 288 p.

9. Kurpatov A.V. Panicheskaya ataka i nevroz serdtsa [Panic Attack and Heart Neurosis]. Moscow, OLMA Media Grupp, 2007. 224 p.

10. Malkova E.E. Trevoga pri somaticheskikh rasstroystvakh u detey i podrostkov [Anxiety in Somatic Disorders in Children and Adolescents]. Meditsinskaya psikhologiya v Rossii, 2012, no. 3 (14). URL: http://medpsy.ru. (accessed February 12, 2017).

11. Nikolaeva V.V., Arina G.A. Ot traditsionnoy psikhosomatiki $\mathrm{k}$ psikhologii telesnosti [From the Traditional Psychosomatics to the Psychology of Corporality]. Vestnik Moskovskogo universiteta. Seriya 14, Psikhologiya, 1996, no. 2, pp. 8-17.

12. Shanina T.G., Filkina O.M., Vorobyeva E.A., et al. Osobennosti funktsionalnogo sostoyaniya vegetativnoy nervnoy sistemy starshikh shkolnikov [Peculiarities of the Functional State of the Autonomic Nervous System of Senior Schoolchildren]. Klinichna pediatriya, 2011, no. 3 (30). URL: http://pediatric.mifua.com/archive/issue-17332/article-21916/. (accessed February 12, 2017).

13. Pokrovskaya N.V. Vegetososudistaya distoniya [Vegetosovascular Dystonia]. Moscow, AST Publ.; Saint Petersburg, Sova Publ., 2009. 128 p.

14. Solovyeva S.L., Nikolaev V.I., Denisenko N.P., Denisenko M.D. Psikhofiziologicheskie kriterii individualnoy reaktsii $\mathrm{V}$ situatsii ostrogo emotsionalnogo stressa [Psychophysiological Criteria of Individual Reaction in a Situation of Acute Emotional Stress]. Meditsinskaya psikhologiya v Rossii, 2012, no. 4(15). URL: http://medpsy.ru. (accessed February 12, 2017).

15. Ragozinskaya V.G., Solovyeva S.L., Nikolaev V.I. Neyrofiziologicheskie korrelyaty emotsionalnykh sostoyaniy u patsientov s psikhosomaticheskimi rasstroystvami [Neurophysiological Correlates of Emotional States in Patients with Psychosomatic Disorders]. Meditsinskaya psikhologiya, 2009, no. 2 (31), pp. 202-205.

16. RomasenkoL.V., Vedenyapina O.Yu., VerbinaA.V. $\mathrm{K}$ kharakteristike psikhosomaticheskikh otnosheniy u bolnykh neyrotsirkulyatornoy distoniey [To the Characteristics of Psychosomatic Relations in Patients with Neurocirculatory Dystonia]. Psikhiatriya $i$ psikhofarmakoterapiya, 2002, vol. 4, no. 1, pp. 12-16.

17. Samushiya M.A., Mustafina E.A. Nozogenii (psikhogennye reaktsii) u zhenshchin so zlokachestvennymi 
opukholyami organov reproduktivnoy sistemy[Noozogenia (Psychogenic Reactions) in Women with Malignant Tumors of Reproductive System Organs]. Psikhicheskie rasstroystva v obshchey meditsine, 2007, no. 3, pp. 11-16.

18. Simanenkov V.I., Grinevich V.B., Potapova I.V. Funktsionalnye i psikhosomaticheskie rasstroystva zheludochno-kishechnogo trakta [Functional and Psychosomatic Disorders of the Gastrointestinal Tract]. Saint Petersburg, LSP Publ., 2006. 651 p.

19. Smulevich A.B. Psikhopatologiya lichnosti $i$ komorbidnye rasstroystva [Psychopathology of Personality and Comorbid Disorders]. Moscow, MED press-inform, 2009. $206 \mathrm{p}$.

20. Solovyeva S.L. Trevoga i trevozhnost: teoriya i praktika [Anxiety and State of Anxiety: Theory and Practice]. Meditsinskaya psikhologiya v Rossii, 2012, no. 6 (17). URL: http://medpsy.ru. (accessed February 12, 2017).

21. Starshenbaum G.V. Psikhosomatika $i$ psikhoterapiya. Istselenie dushi i tela [Psychosomatics and Psychotherapy. Healing of the Soul and the Body]. Moscow, Izd-vo Instituta psikhoterapii, 2005. 496 p.

22. Tkhostov A.Sh., Surnov K.G. Obratnaya storona sotsializatsii. Vliyanie sovremennykh tekhnologiy na razvitie lichnosti i formirovanie patologicheskikh form adaptatsii [The Reverse Side of Socialization. Influence of Modern Technologies on Personality Development and the Formation of Pathological Forms of Adaptation]. Psikhologicheskiy zhurnal, 2005, vol. 26, no. 6, pp. 16-24.

23. Uspenskiy Yu.P., Balukova E.V. Trevozhnye rasstroystva i ikh korrektsiya $\mathrm{v}$ gastroenterologicheskoy praktike [Anxiety Disorders and Their Correction in Gastroenterological Practice]. Consilium-Medicum, 2008, no. 2. URL: http://www.gastroscan.ru/literature/ authors/2200. (accessed February 12, 2017).

24. Chistyakova A.I. Psikhofiziologiya stressa [Psychophysiology of Stress]. Zhurnal estestvennonauchnykh issledovaniy, 2016, vol. 1, no. 5 , p. 2.

25. Chutko L.S. Trevozhnye rasstroystva u detey i podrostkov [Anxiety Disorders in Children and Adolescents]. Trevozhnye rasstroystva $v$ obshchevrachebnoy praktike: rukovodstvo dlya vrachey [Anxiety Disorders in General Medical Practice: a Guide for Doctors]. Saint Petersburg, ELSBISPb Publ., 2010, pp. 55-74.
26. Zhou X., Dere J., Zhu X., Yao S. Anxiety symptom presentations in Han Chinese and EuroCanadian outpatients: Is distress always somatized in China? Journal of Affective Disorders, 2011, vol. 135, no. 1-3, pp. 111-114.

27. Ayers S., Baum A., McManus Chr. Cambridge handbook of psychology, health and medicine. Cambridge, University Press, 2007. 304 p.

28. Reznikova T.N., Terentyeva I.Yu., Kataeva G.V., Semivolos V.I. Metabolic characteristics of brain structures during conscious and unconscious anxiety. Human Physiology, 2008, vol. 34, no. 5, pp. 539-545.

29. Murray L., Creswell C., Cooper P. The development of anxiety disorders in childhood: an integrative review. Psychological Medicine, 2009, vol. 39 (9), pp. 1413-1423.

30. Noyes R., Hoehn-Saric R. The anxiety disorders. Cambridge, Cambridge University Press, 1998. 303 p.

31. Porcelli P., Rafanelli C. Criteria for psychosomatic research (DCPR) in the medical setting. Curr. Psychiatry Rep., 2010, vol. 12 (3), pp. 246-254.

32. Rao D., Young M., Raguram R. Culture, somatization, and psychological distress: Symptom presentation in South Indians patients from a public psychiatric hospital. Psychopathology, 2007, vol. 40, no. 5 , pp. 349-355.

33. Smoller J., Block S., Young M. Genetics of anxiety disorders: the complex road from DSM to DNA. Depress Anxiety, 2009, vol. 26 (11), pp. 965-975.

34. Hall N.M., Kuzminskyte R., Pedersen A.D., Ornbool E. The relationship between cognitive functions, somatization and behavioural coping in patients with multiple functional somatic symptoms. Nordic Journal of Psychiatry, 2011, vol. 65, no. 3, pp. 216-224.

35. Wrana C., Beutel M.E., Knebel A., Lane R.D. Theory of mind and emotional awareness deficits in patients with somatoform disorders. Psychosomatic Medicine, 2010, vol. 72, no. 4, pp. 404-411.

36. Von Känel R. Psychosocial stress and cardiovascular risk: current opinion. Swiss. Med. Wkly, 2012, no. 142, pp. 13-24.

37. Waller E., Scheidt C.E. Somatoform disorders as disorders of affect regulation: a developmental perspective. International Review of Psychiatry, 2006, vol. 18, no. 1, pp. 13-24.

38. Weiss J. Psychocardiology: one heart and one soul. Dtsch. Med. Wochenschr, 2010, Bd. 135 (3), p. 2. 


\section{Information about the Authors}

Rostislav A. Grekhov, Doctor of Medical Sciences, Head of Laboratory of Clinical Psychology, Research Institute of Clinical and Experimental Rheumatology, Zemlyachki St., 76, 400138 Volgograd, Russian Federation; Professor, Department of General and Clinical Psychology, Volgograd State Medical University, Pavshikh Bortsov Sq., 1, 400131 Volgograd, Russian Federation, rheuma@vlpost.ru.

Galina P. Suleymanova, Candidate of Medical Sciences, Leading Researcher, Laboratory of Clinical Psychology, Research Institute of Clinical and Experimental Rheumatology, Zemlyachki St., 76, 400138 Volgograd, Russian Federation; Associate Professor, Department of Psychology, Volgograd State University, Prosp. Universitetsky, 100, 400062 Volgograd, Russian Federation, sgppp22@yandex.ru.

Ekaterina I. Adamovich, Assistant, Department of Pediatric Dentistry, Volgograd State Medical University, Pavshikh Bortsov Sq., 1, 400131 Volgograd, Russian Federation, cheremuha07@rambler.ru.

\section{Информация об авторах}

Ростислав Александрович Грехов, доктор медицинских наук, заведующий лабораторией клинической психологии, Научно-исследовательский институт клинической и экспериментальной ревматологии, ул. Землячки, 76, 400138 г. Волгоград, Российская Федерация; профессор кафедры общей и клинической психологии, Волгоградский государственный медицинский университет, пл. Павших Борцов, 1, 400131 г. Волгоград, Российская Федерация, rheuma@vlpost.ru.

Галина Павловна Сулейманова, кандидат медицинских наук, ведущий научный сотрудник лаборатории клинической психологии, Научно-исследовательский институт клинической и экспериментальной ревматологии, ул. Землячки, 76, 400138 г. Волгоград, Российская Федерация; доцент кафедры психологии, Волгоградский государственный университет, просп. Университетский, 100, 400062 г. Волгоград, Российская Федерация, sgppp22@yandex.ru.

Екатерина Ивановна Адамович, ассистент кафедры стоматологии детского возраста, Волгоградский государственный медицинский университет, пл. Павших Борцов, 1, 400131 г. Волгоград, Российская Федерация, cheremuha07@rambler.ru. 